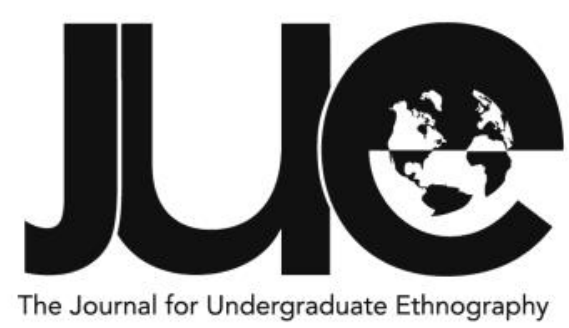

\title{
The Gendered Construction of Border-Crossing in Canada: Immigrant and Indigenous Women's Life Histories in the Tracks of Gloria Anzaldúa
}

Alia Hazineh, Theresa Jbeili, Kathleen Thomas-McNeill*

Dalhousie University

aliahazineh@gmail.com, theresajbeili_1@hotmail.com, kathleenthomasmcneill@gmail.com

\section{ABSTRACT}

Our paper offers a new direction for Canadian scholarship on women and border studies by contextualizing women bordercrossers within Anzaldúa's conocimiento model. Based on the narratives of six women border-crossers in Canada, we argue that citizenship is a form of regulatory state-power where "belonging" is bureaucratically defined. For these women, belonging to a homeland is embodied in the interplay between Anzaldúa's facultad and shadowbeast-between the agency of spirituality and the vagaries of political subjectivity. They crossed the border into Canada, and as a result, the whole of Canada became a borderzone within which they negotiated nepantla (the experience of being "in-between" culture and identity categories). We demonstrate how applying Anzaldúa's framework to the Canadian context yields new insights into secularism, citizenships, multiculturalism, and belonging.

Keywords: conocimiento; nepantla; borderzone; border-crosser; immigration; citizenship; colonialism; secularism; multiculturalism 
- o be a border-crosser in Canada is to belong everywhere and nowhere, to exist in a space where one is simultaneously "of Canada" and "of somewhere else." The act of crossing borders is more than passing over geographical lines. When a woman moves from the Global South to Canada, she carries her homeland and life-experiences in her body, spirit, and mind. Ethnic markers such as language and accent are readily apparent, embodied experiences. However, there are less perceptible factors such as spirituality, education, and experience with violence that create emotional borders. The woman herself is a borderzone; she cannot be understood merely through what others read as embodied markers of ethnic identity. So, what happens when women of colour cross geographical lines and their original frameworks of reality clash and meld with others'? Our paper attempts to reify this in-between space, nepantla, of a woman border-crosser's identity (Anzaldúa 2015). Based on the narratives of six women border-crossers, we argue that Canada objectifies "belonging" through immigration's bureaucratic constructs. Yet, following Gloria Anzaldúa's symbolic system of conocimiento (a process of spiritual inquiry), our data show that true belonging is embodied in the interplay between a woman's imaginative capacity, la facultad, and her internal conflicts, the shadowbeast (concepts that originate from Anzaldúa's Light in the Dark, 2015). We argue that the bureaucratic notion of citizenship does not confer "belonging" but instead works to categorize, dehumanize, and alienate Others. Our research participants crossed into Canada, and as a result, the whole of Canada became a borderzone within which they negotiate their notions of self. By looking through the lens of conocimiento, we trouble the boundaries that colonialism has set up to define identity and belonging based on the binary of inclusion and exclusion, and we uplift the voices of the women living in "global-spiritual terms" (Anzaldúa 2012, 141). These bordercrossing women's identity journeys reflect the long way Canada still must go to become a nation that celebrates difference.

\section{Gendering Canadian Border- Crossers: In the Tracks of Gloria Anzaldúa ${ }^{1}$}

We are forced (or choose) to live in categories that defy binaries of gender, race, class, and sexuality. Living in intersections [...] we must constantly operate in a negotiation mode. Mestizas don't fit with the norm. Depending on the degree of cultural hybridization, we are caught between cultures and can simultaneously be insiders, outsiders, and other-siders. (Anzaldúa 2015, 71)

Gloria Anzaldúa, a Chicana cultural feminist, queer theorist, poet, and much more, is renowned for developing Borderlands Theory. In her words, "my work is about questioning, affecting, and changing the paradigms that govern prevailing notions of reality, identity, creativity, activism, spirituality, race, gender, class, and sexuality. To develop an epistemology of the imagination [...] I construct my own symbolic system" (Anzaldúa 2015, 2). In this study, we look through the lens of Anzaldúa's conocimiento system for an extensive and inherently intersectional understanding of women's embodiment of crossing borders. Conocimiento is a process of spiritual inquiry; it is a way of knowing, seeing, and being in the world. A woman enacts conocimiento through political and creative action, embedding "her experiences in a larger frame of reference, connecting [her] personal struggles with those of other beings on the planet, with the struggles of the Earth itself" (119). Anzaldúa's seven-stage process of conocimiento provides this study with a lens through which we can understand bordercrossers' experiences of self-discovery and belonging. This lens is invaluable as it challenges colonial and bureaucratic interpretations of "identity" and "belonging" while providing an alternative that considers 
the ambiguities of lived experiences. In order to do justice to the robustness of these stages within the scope of this paper, we will focus on the three that the interviews featured most.

- "el arrebato . . rupture, fragmentation . . . an ending, a beginning"(124): an event such as "a violent attack, rift with a loved one, [...] systematic racism, and marginalization" fragments your worldview and breaks down who you used to be (125).

- "nepantla ... . . torn between ways"(126): a liminal space "where the outer boundaries of the mind's inner life meet the outer world of reality, [you are] suspended between shifts, you're two people, split between before and after" (122). Nepantla is the crossroads where border-crossers confront conflicting cultural realities; it is a stage where one (re)develops one's own understanding of life and oneself on a personal and spiritual level.

- "putting Coyolxauhqui together . . new personal and collective "stories"'I' (138): the turning point that pushes you to try to arrange your experiences "into a pattern and story that speak to your reality" (123).

While we only focus on three, all seven stages of conocimiento occur concurrently throughout life (see Anzaldúa's 2015 publication Light in the Dark for an explanation of the remaining four stages). Together, "these stations comprise a meditation on the rites of passage, the transitions of life from birth to death, and all the daily births and deaths in between" (124). Upon embodying these practices and acting on her own vision in daily life, a woman performs spiritual activism.

The seven-stage concept of conocimiento represents the process of Anzaldúa's (2015) new mestiza consciousness theory. Firmly rooted in postcolonial feminism, her theory hypothesizes that if women can own, or "dance upon," their hyphenated identities or mestizaje (abstract noun, like "mixedness"), they fight against the confinement of oppressive, western -defined identity categories. According to Anzaldúa, as a new mestiza, your "resistance to identity boxes leads you to a different tribe, a different story (of mestizaje), enabling you to rethink yourself in more global-spiritual terms instead of conventional categories of color, class, career" (141). These new perspectives challenge the binarism and linear thinking of western ontology. Within the Canadian context, border-crossing women embody an inherently hierarchical hybridization, or mestizaje, of identities; they are, themselves, a borderzone. This new category of identity, mestiza, is a disposition of ambiguity and multiplicity that reflects borderlands as both a physical site and a lived experience (71).

\section{Methodology}

In January of 2019, we met with six women border-crossers living in Canada. Our research consisted of open-ended interviews that were three to five hours in length. In choosing our participants, we sought out diverse geographical representation. The origin countries in our data set include Palestine (Gaza), Venezuela, Lebanon, Zambia, Pakistan, and Mi'kma'ki. In this context, Indigenous women who traverse reserve boundaries and juggle both colonial and home cultures are border-crossers as well. As Audra Simpson (2014) notes, Canadian law works to regulate Indigenous behaviour "to protect, and, in different iterations, to confine and contain the Indigenous in certain spaces" (144). This study's participants ranged between nineteen and thirty-six in age, and they were able to choose their pseudonyms for this report.

Within the scope of a two-term, undergraduate independent study project, the small sample allowed for in-depth, qualitative analysis. Our approach deliberately breaks with traditional anthropological models, which often function to demarcate selffrom Otherand deny the "coevalness" of their informants (Lavie and Swedenburg 1996, 1). At the same time, this work remains fundamentally ethnographic as it is grounded in our informants' perspectives and the social relations that create their realities. We embarked on a feminist-collectivist approach, collaborating with our participants as interlocutors who bring multiple perspectives that cross disciplines and geographical boundaries.

As three women of similar age, completing our undergraduate degrees in diverse disciplines, we, like our research participants, 
bring our own perspectives into this study. With this in mind, we feel that it is imperative to introduce ourselves.

Kathleen is twenty-three years old and finishing her Combined Honours degree in International Development and Gender \& Women's Studies. The most recent firstgeneration immigrants in her family are paternal great-grandparents from Iceland and Scotland who met and married in Canada. Her maternal great-great-grandparents emigrated from Italy in the early 1900s. Tracing her matrilineal genealogy, her ancestors were part of the first wave of Irish settlers in Prince Edward Island during the mid-1700s (notably around the time of the Acadian Expulsion and coinciding removal of local Mi'kmaq communities).

Alia is twenty-one years old and pursuing a Combined Honours degree in Social Anthropology and Contemporary Studies. Like most Canadians, she is of mixed heritage. Her father's family immigrated to Canada in 1967 from Bethlehem, Palestine, a year before his birth. Alia's mother is Scottish-Ukrainian. In an effort to flee the Soviet regime, Alia's maternal grandmother spent her childhood taking refuge in various European cities, arriving in Canada in 1950.

Theresa is a twenty-three-year-old, Canadianborn Lebanese woman. Next year she will pursue a Law Degree at the Schulich School of Law at Dalhousie. Theresa's father immigrated to Canada in 1989, with her mother following shortly after. They left within the context of the Lebanese Civil War, which occurred from 1975 to 1990. They now operate a very successful restaurant in Truro.

\section{Border-Crossers}

The following introductions to the research participants are not mere prefaces. They are the data that led us to employ Anzaldúa's framework to women border-crossers' experiences in Canada. Each woman's journey involved navigating complex and seemingly conflicting identity categories. As these women negotiate their place between these categories, they embark on their process of spiritual inquiry, or in Anzaldúan terms, conocimiento.
Kira

When people ask me where my home is, I feel like they are asking me where I belong, and I don't know [she exhales]. Ask me where I'm from; it's an easier question.

Kira is a twenty-five year old woman from Venezuela. She is passionate, optimistic, and quick to laugh. Even though she struggles to define "home" and find a sense of belonging in Canada, Kira maintains an impressive balance between being headstrong and open-minded. "What do I see when I look in the mirror?" She laughed, "I'm super small, I'm black, and I have super curly hair!" Kira told Kathleen that coming to Canada at nineteen was "the first time l'd moved to a place. [...] I was hanging out all the time with Mexican people, Koreans, and Japanese. [...] It was very different to anything I had lived in my life before." Kira's family was financially privileged in Venezuela, so they enjoyed regular vacations. Laughing, she said, "I'm really grateful that I went to Disneyland so many times because I was kind of familiar with the culture. It wasn't a shock for me when I first came."

\section{Ella}

Sometimes I feel worried to tell [Canadians] I'm Palestinian. But, I'm still Palestinian. Yeah... that's tough. I don't know what [else] to say.

Meet Ella, a twenty-seven-year-old singer, chef, and border-crosser from Gaza, Palestine. Sitting in a coffee shop, behind soft dark curls that frame her almond eyes and tentative smile, she shared with Alia her story of navigating a turbulent, years-long border-crossing experience. Ella continues to reconcile the dramatic changes her new Canadian life brings after living in Gaza for twenty-four years. "I feel like I'm in the process of finding my identity... like, who am I? Am I gonna be still thinking the same? [...] Or, am I gonna be developing my skills and my thinking?" Ella moves through the world with anxiety that stems from no longer being in Gaza. She told Alia, "the question of home is very hard... Home's still home, where I was born in Gaza Strip, Palestine. But for me now, being away from home and all the difficult situations there, I am trying to make my home here in Canada." 


\section{Raissa}

My religion, for sure, has the right of way over anything else. My 'Lebaneseness' also... . If you told me to give [myself] two top identities, it would be my religion and my background. These are two things I don't think I could compromise.

These are the sentiments of Raissa, a twentyfive-year-old Lebanese border-crosser. "[We] came here in 2006," she told Theresa. "My dad is a physician, and he got his degree from a Canadian university. [...] in 2006, he got a locum [a temporary position] in Nova Scotia, and that was the summer when Israel was bombing us [Lebanon]. Because of the... the situation that was going on, all Canadian citizens were asked to leave [Lebanon]. So we'll just go on 'vacation!"' This "vacation" became permanent. Raissa grapples with the fractured familial connections in Lebanon. She shared that it is difficult "missing things that happen and feeling like you want to be over there but you can't... and same for my family [in Lebanon]. They feel like they're missing us and they're missing watching us grow up and living with us day to day." Her smile dissolved as she continued, "When we were living there... we were part of each other's lives directly. Whereas, when you don't live close to each other, you still love them, but... they're not really part of your life, so you don't know what they're like."

\section{Ariel}

At sixteen, I was told that I will be getting married to an older man and will be going to Canada as his bride. [...] Canada was not my choice, it just, like, happened.

Ariel's border-crossing experience played a pivotal role in who she is today. Comfortably nestled on Kathleen's living room sofa, the thirty-six-year-old took a deep breath, pushed her long, auburn-dyed hair from her face, and launched into her story. "I was pretty much pressured into a marriage. [...] A year later I arrived here in my new home and it was miserable. Then, I became a teenage mom." She paused, sipping peppermint tea. "But I think there's a much deeper and more powerful emotional migration story because even though I was physically here, I had never thought of Canada as my home. I wanted to leave because I was being abused in my marriage." Today,
Ariel is a public speaker and a women's rights activist who shares her story wherever she can, from living rooms to international conferences. "When I look back and think, 'Why did I go through all of that abuse..."' She trailed off, staring into the middle distance. "But the work that I'm doing now to help thousands, if not millions, of people around the world... I love it. It gives me meaning and purpose and wakes me up every morning."

\section{Lila}

Going back home, my African friends [say], 'Oh, you're so Canadian.' I'm like, 'No! I'm in the middle!' I feel offended [...] 'cause I want [them] to know that yes, I grew up here [in Canada], but I'm still Zambian, right?

Lila is a twenty-two-year-old university student from Zambia. On a chilly Thursday afternoon, she met with Alia outside a campus study room. Lila wore bright colours that mirrored her playful humour and vibrant smile. She laughed often throughout the three-hour interview as she described the struggle of finding a space where cross-cultural expression between Zambian and Canadian traditions and values was comfortable. "Home," she explained, "is a little bit of both places. I'd probably start off by saying home is where I'm from, Zambia. But, I would also include Nova Scotia because this is where I was raised." For Lila, negotiating the concept of "home" is an intricate dance between two cultures that continue to complicate and torment each other. She confessed her deep love for her Zambian homeland and the essential role that family, "the most important thing," plays in her life.

\section{Willard}

I was taught that being Mi'kmaq wasn't about how you looked. It was about the way you acted throughout society and the way you viewed the world. It wasn't your skin. Since I knew that from such a young age, for [other children] to try and say I wasn't Mi'kmaw just because of the colour of my skin was so weird because [...] everything $\mid$ do is Mi'kmaw, every day.

Unlike our other research participants, Willard, a nineteen-year-old woman from Indian Brook, Nova Scotia, has been a border-crosser from childhood. She met with Theresa in the kitchen 
of her Victorian-style townhouse. Willard currently lives in Halifax while attending university but has to cross "colonial borders" when visiting family on the reserve. As an Indigenous woman, Willard often collides with labels like "status" and "borders," terms she refers to as "colonial expressions." She explained to Theresa, "It sucks that I have to say full status 'cause, like, that's a colonial thing. But it's literally a daily part of our life; the only way I can talk about that is if I literally use a colonial term." Willard associates home with her life on the reserve, where her entire community is her family. "The Canadian culture is more [...] capitalist-based. Everyone's just trying to get their own nuclear family into the best it can be. [...] They only care about themselves and their family."

\section{The Lacuna: Canada's Neglect for Spirituality and Religion in Discussions of Immigration}

As we reviewed the literature, we discovered a lacuna in Canadian border-crossing research. The bureaucratic process of Canadian citizenship is secular; thus, many assume that border-crossing and "integration" are also secular experiences. Canadian immigration literature is a classic example of confirmation bias, favouring information that confirms society's preexisting beliefs. That is to say, Canadian secularism tends to demote spirituality and religion to a somewhat ambivalently respected and even inconsequential aspect of identity. For example, in Madine VanderPlaat's (2007) comprehensive review of Canadian literature on immigrant women's integration, religion is referenced only once in the context of Muslim women's experiences job hunting while wearing hijabs. Spirituality and religion are, to varying degrees, principal facets of culture. This is a critical point, as culture informs our behaviour and provides the framework through which we understand our surroundings, our experiences, and our positionality (9). As such, our findings suggest that the experience of border-crossing is anything but an exclusively secular endeavour.

In Canadian literature, the border is defined almost exclusively in geographical terms and refers to the border-crossing woman as an immigrant. This approach treats her challenges as speed bumps along a linear path from point $A$, the initial act of crossing the border, to point $B$, social integration and citizenship. This linear framework is adverse to Anzaldúa's (2012) nonlinear, multifaceted definition of borderzones. For her, a borderzone is physical, emotional, and spiritual; it is "where the Third World grates against the first and bleeds [...] a vague and undetermined place created by the emotional residue of an unnatural boundary [...] a constant state of transition" (25). We draw on Anzaldúa's approach to analyze our findings, as it incorporates the entirety of a woman border-crosser's experience, especially the interwoven thread of spirituality and religion. Popular literature's neglect of these influences is partly a result of Western scholars' research parameters. According to Smadar Lavie (2018), "colonial idealism is still at the very heart of scholarship, because funding for research and publications is mostly situated in North American and Western European institutions that set the research agenda" (29). Canadian research on immigration is generally conducted within patriarchal institutions that value secularism's "rationality" and science's "objectivity." As such, Canada's "invisibilization of the familiar" (the continued depersonalization, bureaucratization, and securitization of border-crossing experiences, in this context) compels its immigration literature to eschew spirituality as a critical area of analysis (Chew 2009, 87).

\section{Sketching the Ancestors of Canadian Border-Crossing Literature}

Although lacking in spirituality-inclusive research, Canada has a substantial body of literature that focuses on holistic life experiences, including intersectionality, identity, and belonging. In what follows, we give space for the five scholars whose ideas were fundamental in guiding and supporting our research in this field.

\section{Intersectionality}

Some of the first Canadian ethnographic research on women border-crossers was done in 1988 by Dr. Helen Ralston, a professor at Saint Mary's University in Halifax, Nova Scotia. 
Ralston's work looks at the experiences of class, gender, and ethnicity for women bordercrossers. Her intersectional model marks her work as exceptional for its time. Another early work comes from Roxana Ng (1981). Her radical ethnographic fieldwork with immigrant women in Vancouver highlights ethnicity as a concept created after the border-crosser enters Canadian society. $\mathrm{Ng}$ argues that Canadians are actively involved in the process of enacting ethnicity and race in our everyday lives. When a border-crosser enters Canada, their race and ethnicity become a means by which other Canadians understand and engage with them in productive and social environments.

\section{Identity and Belonging}

Gillian Creese's (2005) work, Negotiating Belonging: Bordered Spaces and Imagined Communities in Vancouver, Canada, explores the psychosomatic space where bordercrossers negotiate their positionality between cultures. Interestingly, Creese is the only feminist Canadian author we found who references Anzaldúa. Her work heavily informed our understanding of what it means to "belong" to a homeland. According to Creese, women border-crossers' senses of belonging are "often ambiguous, contradictory, and at best, partial" in Canada (24).

Audra Simpson's (2014) Mohawk Interruptus: Political Life Across the Borders of Settler States explores how North American colonial bureaucracies work to regulate and even suppress the Indigenous peoples' selfdetermination efforts. Simpson's work set the basis for our understanding of the connections between history, policy, and continued colonial violence and how they work together to perpetuate the subjugation of Indigenous peoples-which we found also applies more broadly to minority populations within Canada.

In her work Homegrown, Muslim and other: tolerance, secularism and the limits of multiculturalism, Eve Haque (2010) frames Canadian diversity policies and cultural mentalities within the context of "multiculturalism within a bilingual framework" (81). We engage with Haque's analysis of the insidious relationship between secularism, multiculturalism, and white supremacy to contextualize women border- crossers' experiences within Canada's continued affirmation of colonial power hierarchies.

While all of these authors' works were valuable to our overall understanding of the issues discussed in this paper, none engaged with spirituality or religion's impact on the border-crossing experience in Canada. For this reason, we use Anzaldúa's (2012; 2015) work not only to illuminate women's border-crossing experiences but also to expand Canada's secularist immigration discourse.

\section{I. el arrebato... rupture, fragmentation ... an ending, a beginning}

You are no longer who you used to be. [...] abandoned by all that's familiar. Exposed, naked, disoriented, wounded, uncertain, confused, and conflicted, you're forced to live en la orilla-a razor-sharp edge that fragments you. (Anzaldúa 2015, 125)

The "fragmentation" that a border-crossing woman confronts when she enters Canada is entangled in the hegemonic landscape of systematic racism and marginalization (125). This experience is unique, for as she becomes "Canadian," social structures work to delegitimize her "global-spiritual" mestiza identity. Consequently, her understanding of the world and herself breaks down.

Multiculturalism as an ideal seems to imply equality and interconnectedness, and it does have this potential in Canadian society. However, up to this point, Canadian multiculturalism continues to perpetuate ethnic power hierarchies. The political discourse around multiculturalism emerged during the Trudeau Era in the 1960s when post-war Canada sought to challenge the existing hierarchy of Anglo-Celtic dominance, most visibly from French Canadians. Eve Haque (2010) discusses how, during this time, Canadian "national belonging was shifted from overt racial preferences onto the terrain of language and culture to produce the Official Languages Act (1969) and [...] the Multiculturalism Policy (1971) which together gave rise to Trudeau's ostensibly seamless linguistic and cultural policy of 'multiculturalism 
within a bilingual framework"' (81). The duality of this grouping, while it sought to calm AngloFranco tensions, also served to "erase the founding status of Indigenous peoples and render 'the Other ethnic groups' [...] as mere cultural communities peripheral to the nowacknowledged 'two founding races,' the French and English" (81). "Other ethnic groups" was how all non-French and non-English "immigrant groups" were defined legally during the commissions. It is precisely this framework that carries the "us" (white, Anglo/Franco citizens) versus "them" (border-crossers of colour/ differing religions) maxim throughout Canadian multiculturalism.

Understanding the Canadian multiculturalist formula's duality is crucial because it provides the basis for one of its most essential cornerstones: secularism (82). Canadian secularism is predominantly based on laicité, the historic religion-state model of 18th century France (Wallace 2014, para. 21). The European secularist movement was not centrally about tolerance; it served as a way to wrest control from the Church, privileging the Enlightenment period's rationality and individualism (Chew 2009, 87). According to Dolores Chew (2009), the ideology of secularism "fit well with the project [of] 'western civilization,' with its assumptions of progress and development" (87). The aim of laïcité, or secularism, was not to outlaw religion but to restrict and control it, particularly as it grew in tandem with the differentiation of the public and private social space (Wallace 2014, para. 21).

\section{Canadian Secularism, but with a Christian}

Flavour

Many Canadians believe that our country, as a secular liberal nation, guarantees the "separation of church and state," or religious influence in public life. Instead, as these women border-crossers' narratives suggest, through secularism, the liberal state exercises sovereign power and determines which religious expressions are acceptable in the public sphere (Haque 2010, 82). In Canada, "proper" religious expressions are Christian. When the French and British colonized Turtle Island, renamed North America, they brought their Christian religionstate traditions (Wallace 2014, para. 15). By the end of the 17th century, the Church of England, for example, controlled Upper Canada, and the Roman Catholic Church held Lower Canada (para. 15). Due to the colonial roots and amplified by the "white settler hegemony of 'multiculturalism within a bilingual framework"' (Haque 2010, 79), European Christianocentrism is ubiquitous in Canadian culture. Lila acknowledged this phenomenon when she told Alia, "Canada has been accommodating [to my family's Christian practices], but only because Christianity is [...] the dominant religion in the Western world." Today, we can see Canadian society's continued subconscious allegiance to Christianity in the way we operate around a Christian calendar. Only Christianity is universalized and is entitled to designated paid holidays. For example, Canadian religion-based statutory holidays include Good Friday, Easter Monday, and Christmas Day. Evidently, the Christian religion is far from being kept out of the public sphere.

At present, what Canadian secular, multiculturalist "diversity" permits, specifically in terms of non-European Christian expression, is quite limited. For instance, Raissa is a Maronite, a sect of Christianity that originates in Syria but is now firmly rooted in Lebanon. When asked about how she believes Canadian people outside of her Church view her religion, she said, "They think it's silly. They have a different perspective and [...] it's not relevant [to them]." Since Canadians minimize Raissa's religious experience, she avoids discussing her beliefs altogether. According to Chew (2009), this restriction on "diversity" is an effect of secular fundamentalism. Distinguished from secularism (that is, the separation of Church and state), secular fundamentalism is the extreme sect that calls for policies and laws such as Quebec's ban on religious symbols through Bill 21 (an Act respecting the laicity of the State) in 2019. These policies disproportionately affect non-white religious expression, which highlights Canada's allegiance with colonial Euro-Christian values. To this point, Willard explained that she is often challenged by the distinct lack of places where she can smudge. She told Theresa, "Even in one of my Indigenous classes right now, the instructor has been wanting to do, like, a blanket exercise, but in order to do that, you 
have to smudge to start the exercise. And a lot of the rooms don't accept smudging." As Raissa and Willard's experiences suggest, not all types of religious and spiritual expression are accepted or even possible in the Canadian public sphere. This means that Canadian multiculturalist policy can, and in many ways does, serve as a smokescreen for secularist exclusionary practices.

\section{Bureaucracy: A Pilgrimage Through Uncertainty}

We are experiencing a personal, global identity crisis in a disintegrating social order that possesses little heart and functions to oppress people by organizing them into hierarchies of commerce and power. (Anzaldúa 2015, 118)

Lavie's (2018) research challenges the notion of bureaucracy as a secular, rational system by highlighting the critical role uncertainty plays in bureaucratic negotiations and processes. While her work focuses on Mizrahi women in the State of Israel, this concept of bureaucratic uncertainty as a state regulatory power also applies to Canadian colonialism in immigration. According to Lavie, the goals of women negotiating the uncertainty of bureaucracy parallel "the goals the faithful have when they go on pilgrimage" (23). Ella shared a story regarding this kind of uncertainty, illustrating the paralleled experiences of chance, faith, and prayer between pilgrims and women bordercrossers negotiating the bureaucracy of immigration. "I think I learned how to be patient," she laughed.

I was so frustrated at the beginning. [...] I was really worried about my family at the time because the situation is getting worse [in Gaza] and it's not safe, and my process is taking a long time. My hearing is postponed. I don't know how I'm going to get them here or try and help them. So, it was really tough. And my lawyer said, like, 'I'm sorry but you are seeking asylum so you can't really help your family because it's your story, your thing to do.' I was like, 'Oh, I didn't know that. I thought when I claim asylum, I can help them to come here.' Because when you do immigration it's different than seeking asylum, it's different than just staying here and working, and then getting your PR and stuff.

Canadian immigration has its own bureaucratic logic. According to Ella, "Even though there is a process, it does come off like it's really simple and very welcoming. But there's so much that goes into it that we don't really notice until we go through it and then it's like, 'oh wow,"' she concluded apprehensively. Even though Lila came to Canada from Zambia in 2001 at the age of six, she did not receive permanent residence until her first year of university. She talked about the years of paperwork and uncertainty that her parents faced while paying lawyers who ended up being extremely negligent. In 2014, when Lila still did not have permanent residence, Nova Scotia Immigration wanted to deport her father whose papers had expired.

Canadian multiculturalist policy maintains that multiple cultures coexist within one unified (homogenized) "Canadian" culture. This system of thinking secures the ethnic hierarchies in our immigration bureaucracy; the white man of European/Protestant origin continues to be considered the "neutral" against which difference (and thus the allocation of citizenship privileges such as rights, security, and protection) is measured. Today, we can see tensions arise as Canadian demographics become increasingly heterogeneous with the influx of non-Christian cultures and religions (Haque 2010). As Creese (2005) argues, "transnational migration creates new forms of multiply-positioned subjects and cultural hybridities that, in so far as they destabilize national boundaries, may be potentially transgressive" (3). Canada's shifting demographics challenge not only the current secular attitude but also white, Christian, European privilege.

\section{Nepantla, the In-Between: Torn Between Conflicting Realities}

After leaving the home culture's familiar cocoon, you occupy other ideological spaces, begin seeing reality in new ways, questioning both the native culture's and the new culture's descriptions of reality. (Anzaldúa 2015, 71)

Canada's secular model pits homogenized, white/European Canadian identity against 
particular non-western cultural expressions. This social configuration creates a "rupture," or an "us" against "them" dichotomy, that bordercrossing women must negotiate. In the next section, we explore this negotiation through Anzaldúa's conocimiento stage of nepantla. All of the women in this study felt pulled between conflicting realities-the norms of Canada's white majority and the familiar norms of their homeland.

\section{Not So Polite: Canadian Racism}

There is a ubiquitous boundary that exists between secular subjects and non-liberal fundamentalist cultures. In this atmosphere, the boundary between what, to the hegemonic universal, is tolerable and what is not becomes a practice of demarcation (Haque 2010, 84). The nature of the demarcation-or what is, in reality, "tolerable"-is hardly predictable. Roxana Ng (1981) argues that the point at which ethnicity becomes significant for bordercrossing women is when they are perceived as not performing adequately (103). For example, Ella shared an experience of closing her cafe one day when "a guy came and said, "I just realized that you're not white, not Canadian.' [Then he] kept asking me about drinks and telling me to make them certain ways, like I didn't know. He was being really rude to me." Willard also spoke to this when she described Canadians' confusion at her mother being both Mi'kmaw and a lawyer. Willard said, “it's almost like they don't even realize they're being racist [...] because it's just been such a societal norm that if you're a marginalized person you usually don't achieve things like that." To this, Anzaldúa (2015) writes, "Exchanges with self, others, and world arouse antagonism when others don't react as you expected" (77). Here, we see that the association of Indigenous identity with poverty runs so deep that Canadians struggle to correlate it with prestige.

These simplistic assumptions, reinforced by Canada's Euro-Christianocentrism and secular multiculturalism, illustrate yet another insufficiency in the demarcation practice of cultural Others. These demarcation practices contribute to the "us versus them" discourse by assuming that "Others" (ethno-cultural minority groups) are ahistorical and static and subscribe to changeless cultural norms. As Anzaldúa (2012) argues, the mestiza "has had to work twice as hard as others to meet the standards of the dominant culture which have, in part, become her standards" (71). This tenuous structure perpetuates social "ruptures" and serves to cement Canada's racialized, ethnocultural hierarchy. It also distorts what fluidity exists between majority white and minority non-white cultures by overlooking their interconnectedness.

\section{The Shadowbeast. A Case of Mistaken Identity Politics}

While home, family, and ethnic culture tug you back to the tribe [...] the anglo world sucks you toward an assimilated, homogenized, whitewashed identity. Each separate reality and its belief system vies with others to convert you to its worldview. (Anzaldúa 2015, 126)

According to Anzaldúa (2012), many bordercrossing women conform to the values of the "new" culture to avoid rejection; they "push the unacceptable parts [of themselves] into the Shadows" (42). However, a mestiza who succeeds in identifying her shadowbeast through spiritual activism sees it for what it is: her inner rebel (42). Her negotiation with rigid, seemingly incompatible belief systems is a negotiation with her shadowbeast. As such, the shadowbeast works on both a collective and personal scale.

A border-crosser's shadows are the parts of herself that refuse to be constrained by Anglo/ Western hierarchical structures. In Canada, both Ariel and Ella's shadowbeasts manifest similarly in their desires to distance themselves from Arab and South Asian men. Ariel's marriage was rife with emotional, physical, and financial abuse. It has been many years since Ariel left her marriage; however, she makes it clear that, "I don't mingle with Pakistanis and South Asians too much. I feel like there's always going to be judgement there. [...] I faced a lot of backlash when I left my marriage. [...] It was ugly, and all from that community. So, I just stay away." On the topic of dating, Ella announced, unprompted, that she would never be with an Arab man. She stated categorically, "I hate Arab men." These women find themselves in the shadow of Canadian culture where Arab and 
South Asian presenting phenotypes are harshly judged. They have internalized a belief system (based on a range of experiences), wherein minority cultures, specifically Arab and South Asian men, are ahistorically viewed as controlled by immutable customs. This is extremely pertinent in the Global North's current climate, where we are witnessing increasing surges of Islamophobia. While one must guard against the ease by which "Arab and Pakistani men" and "violence" slide into a common category, there are very real patriarchal manifestations of violence within Muslim countries that exist to varying degrees in all cultures (Christian patriarchy, for instance). These issues are multilayered, complex, and informed by many factors, including these women's personal experiences both in Canada and in their countries of origin.

\section{What's Language Between Friends?}

Language is the primary tool used to negotiate various signifiers of cultural differences; however, language itself can serve as an exclusionary practice. In this context, women border-crossers' external and internal experiences of linguistic estrangement highlight their journey through nepantla. Jhumpa Lahiri (2016) argues that "when you live in a country where your own language is considered foreign, you can feel a continuous sense of estrangement. You speak a secret unknown language, lacking any correspondence to the environment. An absence that creates a distance within you" (19). Lila described her experience of external linguistic estrangement to Alia. She felt left out whenever her extended family came to visit because nobody spoke to her in English. "Immediately all kinds of languages are running through [my home], and as much as I do hear everything [...] I'll always be replying in English and then I feel kind of alienated." Even though English is an official language of Zambia and her entire family can speak it, they mainly choose to communicate in their Bemba dialect when they are together, which Lila cannot speak fluently.

Language is a primary tool of selfexpression. When a border-crossing woman cannot express herself in the language of the majority, she experiences internal estrangement. Kira's inability to "talk normally" frequently frustrates her. Humour is integral to her personality and is, therefore, crucial in her relationships. She described how the critical connection between fluency and humour often left her feeling lonely:

[It's] how you say words, how you put them in a sentence, especially when you don't speak the language, [...] you can't be as funny, or you can't be as fun in general. Like, you have sarcastic tones that you can't express, and when you actually get them out, they are too slow to be funny. It's infuriating! Everyone's like, 'Oh, yeah, yeah she's okay...' and it's like, no, I'm not just okay, I'm awesome! I swear!

She ended with a laugh. For Kira, not being able to express her humour was an obstacle that made her feel disaffected in Canada. She said, "I really miss having close friends like I had before [in Venezuela]." In this sense, Kira and Lila's experiences are two sides of the same coin. Where Lila's fluency in English inhibited her from genuinely connecting with her family, Kira's struggle with English left her ability to make friends tenuous.

Language deficiencies impede a woman border-crosser's ability to navigate the nuances of cultural differences. Since she is not familiar with the colloquial context, euphemisms may be lost on her, which creates a sense of cultural alienation. Raissa astutely pointed out, "Language is a reflection of culture. So, the expressions used in the language reflects the type of culture it is, and what the priorities of a culture is." In her experience, she noted,

I find it really, really difficult to connect with people who are born here. This is their culture. [...] I feel like an outsider because I can't connect [with them]. [...] But with my international friends, whenever we start talking about how we don't feel like we fit in... You feel like you belong in that group right away because you have something in common with them, [...] you feel like people view you differently.

A big part of "feeling included" is contingent on one's ability to understand the underlying intracultural (inside) jokes. For Raissa, not understanding cultural-linguistic contexts made her feel like she did not belong amongst her 
Canadian peers. For women border-crossers, or mestizas, establishing relationships while experiencing cultural alienation is incredibly difficult. Raissa suggested as much when she spoke of feeling disconnected from her Canadian-born peers. This is why bringing Anzaldúa's nomenclature into a Canadian border-crossing context is so important: It acknowledges and reifies both mestizas' spiritual agency and the vagaries of political subjectivity that the state prefers to ignore.

\section{Coyolxauhqui, a Community: A New Personal Narrative}

Your resistance to identity boxes [...] calls you to retribalize your identity to a more inclusive one, redefining what it means to be [...] a citizen of the world, classifications reflecting an emerging planetary culture. In this narrative, national boundaries dividing us from the 'others' (nos/otras) are porous, and the cracks between worlds serve as gateways. (Anzaldúa 2015, 141)

Canada is a space where multiple cultures coexist and thrive. Yet, for too long, Canada's colonial, secularist, bureaucratic imperatives have mandated that women border-crossers deny their mestiza identities and assimilate into predetermined identity categories to become "true" Canadians. In the following section, we explore some methods that these women use to refuse the suffocating limitations of Canadian identification practices. Through the lens of Anzaldúa's conocimiento stage of Coyolxauhqui, where new personal and collective narratives emerge, we can see how Canada can provide mestizas with a unique space to explore the cracks between culturallydefined identity borders. In this stage, one "owns [their] shadow, allowing the breath of healing to come into [their] lives" (Anzaldúa 2015, 123). As this process unfolds, Canada becomes the borderzone where these women dismantle rigid perceptions of identity and belonging. Willard articulated this effect beautifully when she asserted her Mi'kmaw identity's boundlessness that is neither singular nor determined in advance. She told Theresa, "everything I do is Mi'kmaw, every day." For her, being Mi'kmaw does not mean anything other than being exactly who she is every day-on and off the reserve. In every moment of Willard's multidimensional identity, she is Mi'kmaw.

\section{Bucking the System: What is a Woman?}

You realize that some aspects of who you are-identities people have imposed on you as a woman of color and that you have internalized-are also made up. Identity becomes a cage you reinforce and doublelock yourself into. The life you thought inevitable, unalterable, and fixed in some foundational reality is smoke, a mental construction, fabrication. So, you reason, if it's all made up, you can compose it anew and differently. (Anzaldúa 2015, 138)

When we asked the women to define "womanhood," their initial answers paralleled a traditional patriarchal definition comparing women against men. She is what he is not. Kira shared that being a woman meant "being scared of dressing in a certain way, or being scared of what people are going to think if I dress that certain way." Ella said, "Sometimes I felt like, why wasn't I a man who had control [and] could do things?" These looming patriarchal perceptions of being a woman exemplify a manifestation of a collective shadowbeast-mainstream Anglo culture's implicit categorization of womanhood.

However, as these women pondered the question, their answers shifted. The narrow definition of womanhood evolved to one that reached beyond stereotypes. Kira noted, "Those are imposed things. [...] They are not real!" Throughout the interview, they began to articulate "womanhood" in their terms. When Lila described her identity, she proudly declared, "I'm a Black woman [...] and the idea of the femme is a powerful thing, even if society may not see it that way. Women have a lot of power in that we raise people [...] That's really powerful whether or not you're a mother." Ella commented, "Understanding yourself as a woman every day makes you feel like, no I don't want to be a man... I can be responsible for things. I can carry heavy things." Ariel concurred, wrapping everything up with, "I think because I was told that because I am a girl I couldn't do this or that, it has just kind of made me more rebellious. Like, I'll show you, watch me!" 
Since neither Anglo-secular norms nor the familiar norms of their birthplaces adequately served their personal understandings of womanhood, these women challenged their inner facultad (their ability) to accommodate "mutually exclusive, discontinuous, and inconsistent worlds" to create a new narrative for themselves (Anzaldúa 2015, 81). Essentially, the mestizas channelled their facultad by turning inward to engage the shadowbeast and their inner resilience.

\section{Back to the Drawing Board: Overriding the Colonial Binary}

When I write [...] [it] feels like I'm creating my own face, my own heart - a Nahuatl concept. My soul makes itself through the creative act. It is constantly remaking and giving birth to itself through my body. It is this learning to live with la Coatlicue that transforms living in the Borderlands from a nightmare into a numinous experience. (Anzaldúa 2012, 95)

Ariel embodies Coyolxauhqui in her active renegotiation of her personal narrative. After leaving her abusive marriage, she created a new, independent life for herself and her children. In essence, there existed a kind of "internal split" for her: before and after, Pakistani culture and Canadian culture, old self and new self. Ariel subsumed her younger self into a shadowbeast through shame, humiliation, and anger, internalizing this dichotomy.

In March 2019, Ariel published her autobiography. The cover is her wedding photo: a seventeen-year-old girl in traditional Pakistani wedding garb. She told Kathleen, "When my book cover was being designed [...] I was having fights with my publisher. [...] I don't identify with that scared mouse on the cover anymore. I don't like her. The woman in the red heels and the western dress, the strong power figure, that's me." A few months later, Ariel was a keynote speaker at a graduation in Ottawa. As she was handing students their degrees, she had an epiphany. "[l]t just struck me that I was on stage at that age to get married... That's how old I was in that picture, on the cover. And these kids, they were coming on stage to get the degrees." For the rest of the ceremony, Ariel sat on the stage and thought about her seventeen-year-old self. She marvelled at how "she was the one who did not give up on her education, who did all the chores during the day, served her in-laws, cooked the food, and still went into her room in the middle of the night and studied and completed her high school without any support." Since that moment, Ariel has had a very different attitude towards that young woman. "I'm like, 'holy fuck.' [...] If I hadn't fought all those hard battles then, I wouldn't even be who I am today. [...] I just felt so much compassion for this little girl that was me. [...] If there's anyone who's the hero of the story, it's her, and if there's anyone who deserves to be on the cover, it's her." After the graduation, Ariel went back to her hotel, opened the book cover on her phone, and "sat there for an hour crying and saying thank you to that girl." She called her publisher the next day and said: "'The cover's fantastic."'

Reconciling her past and present, Ariel was able to reclaim foundational moments integral to her identity as a border-crossing woman. She overrode the shadowbeast that deemed her identities incompatible and reified the fluidity that exists between them. The graduating students inspired Ariel to walk through a spiritual gateway, and she put herself back together on her own terms.

Canada's various colonial borders that separate "us" from "them" often emanate from the liberal intention to create one unified community where diverse cultures can coexist in harmony. The disjuncture, however, is that the state uses secular assimilation to achieve this goal. This results in the erasure, for example, of Indigenous worldviews that draw their ethical frameworks and governance systems from the deeply empathetic, respectful, and reciprocal relationships among people and the earth. In contrast to Canadian secularism, Willard explained that Mi'kmaq culture is inherently altruistic and recognizes the "interconnectedness" between all beings, cultures, and ways of knowing. "We would still recognize that parts of their [Canadian] culture are intertwined in ours [...] out of respect." Willard exemplifies Smadar Lavie and Ted Swedenburg's (1996) argument that "borders and diasporas offer new frames and analysis that resist and transcend national boundaries" (15). Willard's facultad is the 
inherent recognition of the colonial binary way of thinking and her constant renegotiation of her mestiza identity as a life-long crosser of colonial borders.

\section{Laugh and the Whole World Laughs with You: Conclusion}

Stubborn, persevering, impenetrable as stone, yet possessing a malleability that renders us unbreakable, we, the mestizas and mestizos, will remain. (Anzaldúa 2012, 86)

This paper is a platform for the narratives of six women border-crossers in Canada; their narratives are given space, influence, and power, both within their own contexts and within Canadian academia more broadly. As these women evolve through conocimiento, they become their own "borderland" where colonial perceptions of "Canadian identity" begin to unravel through reflective and creative dialogues. For them, the whole of Canada becomes a borderzone within which they negotiate nepantla, reconciling their facultad and shadowbeast and claiming for themselves a mestiza identity that hybridizes all of their border-crossing experiences. Canada's Anglosecular landscape has neglected and overlooked the complexity of mestiza consciousness and the inherent spirituality that frames this experience. Bringing Anzaldúa's (2012; 2015) works into the Canadian context gives us the ability to articulate this new mestiza consciousness and shift the structure that dominates prevailing notions of identity, spirituality, race, gender, class, and sexuality.

We often hear that Canada's beauty and significance is its quintessential diversity. But this difference must be effectively articulated if diversity is to be embraced and celebrated authentically. The more we uplift and give space to the mestiza experience, the closer Canada will come to the multicultural nation it claims to be.

Canada's multicultural landscape is no utopia, but we uncovered it to be a place rich with potential. As these women bordercrossers' stories attest, Canada can provide a space for a diverse range of positive selfdiscovery and spiritual activism. In the words of
Ariel, "If you choose not to take part in a set of cultural values that you do not agree with, then you will find another community and another set of values that you will align yourself with."

These six women's experiences, a microcosm of a far greater population, demonstrates the need for a broader immigration lens, one that acknowledges the folly of predetermined, onedimensional border-crossing narratives. The "problems of difference" that we face in a globalized world lack effective solutions. To progress, our understanding of the world must be "broader than the Western understanding of the world" (Escobar 1988, 16). One way forward is to understand how Canada's secular fundamentalism and Christianocentrism inhibit nuance, a critical aspect of understanding immigrants, refugees, and asylum seekers as complex human beings. Negotiating diverse and often seemingly contradictory perspectives has never been more crucial. When we legitimize multiple perceptions of "what exists," we create spaces where new and better cultural narratives can grow. This approach can go some distance in counterbalancing lingering worldviews that promote violence and prejudice with the hope of minimizing the "us" versus "them" mentality. One example is the dire need to decolonize our conception of Indigeneity as a subaltern "culture." We must support Indigenous activists in their attempts to educate Canadians on how to break the colonial monopoly on legitimate forms of knowledge. Using Anzaldúa's (2015) model, we conclude that women border-crossers offer Canada a unique opportunity. In order to bring Canadian diversity to its full potential, we must understand and integrate the more nuanced aspect of spirituality in women border-crosser's life experiences. As globalization endlessly redefines geographic and socio-political borders, the border-crosser is becoming the new human archetype. It is time we recognize the mestiza as an authentic form of political subjectivity. 


\section{Acknowledgements}

We would like to thank the brilliant women who dedicated their time and energy to share their stories. We are incredibly grateful for your openness and willingness to collaborate with us. We would also like to thank our professor, mentor, and friend, Dr. Smadar Lavie, who gave us endless hours of academic guidance and emotional support throughout. The collaborative efforts of all of the women involved have resulted in a project of which we can all feel proud.

\section{Endnotes}

1. This heading is inspired by Norma Alarcon's paper titled Chicana Feminism: In the Track of "the" Native Women. 


\section{References}

Anzaldúa, Gloria. 2012. Borderlands/La Frontera: The New Mestiza. 4th ed. San Francisco: Aunt Lute Books.

Anzaldúa, Gloria. 2015. Light in the Dark: Luz en lo Oscuro: Rewriting Identity, Spirituality, Reality. Durham: Duke University Press.

Chew, Dolores. 2009. "Feminism and Multiculturalism in Quebec." Canadian Woman Studies 27 (2-3): 84-92.

Coulthard, Glen, and Leanne Simpson. 2016. "Grounded Normativity / Place-Based Solidarity." The American Studies Association 68 (2): 249-255.

Creese, Gillian. 2005. Negotiating Belonging: Bordered Spaces and Imagined Communities in Vancouver, Canada. Burnaby: Vancouver Centre of Excellence.

Escobar, Arturo. 1988. "Power and Visibility: Development and the Invention and Management of the Third World." Cultural Anthropology 3 (4): 428-443.

Haque, Eve. 2010. "Homegrown, Muslim and Other: Tolerance, Secularism and the Limits of Multiculturalism." Social /dentities 16 (1): 79-101.

Lahiri, Jhumpa. 2016. In Other Words. Translated by Ann Goldstein. New York: Alfred A. Knopf.

Lavie, Smadar, and Ted Swedenburg. 1996. Displacement, Diaspora, and Geographies of Identity. Durham: Duke University Press.

Lavie, Smadar. 2018. Wrapped in the Flag of Israel. Lincoln: University of Nebraska Press.

Mahmood, Saba. 2006. "Secularism, Hermeneutics, and Empire: The Politics of Islamic Reformation." Public Culture 18 (2): 323-347.

Ng, Roxana. 1981. "Constituting Ethnic Phenomenon: An Account from the Perspective of Immigrant Women." Canadian Ethnic Studies/Études ethniques au Canada 13 (1): 97-108.

Ralston, Helen. 1988. "Ethnicity, Class and Gender Among South Asian Women in Metro Halifax: An Exploratory Study." Canadian Ethnic Studies/Études ethniques au Canada 20 (3): 63-83.

Simpson, Audra. 2014. Mohawk Interruptus: Political Life Across the Borders of Settler States. Durham: Duke University Press. 
VanderPlaat, Madine. 2007. "Integration Outcomes for Immigrant Women in Canada: A Review of the Literature 2000-2007." Atlantic Metropolis Centre: Working Paper Series. Working Paper No. 8 - 2007. http://community.smu.ca/atlantic/documents/ vanderPlaat-wp8.pdf.

Wallace, James. 2014. "Misunderstood and Mischaracterized: Canada's Four Models of Religion-State Relations." Presented at the 4th Annual Parliamentary Forum on Religious Freedom, Ottawa, May 26, 2014. Accessed April 19, 2019. http:// www.davidanderson.ca/canadas-four-models-of-religion-staterelations/.

Willen, Sarah. 2010. “Citizens, 'Real' Others, and 'Other' Others: The Biopolitics of Otherness and the Deportation of Unauthorized Migrant Workers from Tel Aviv, Israel." In The Deportation Regime: Sovereignty, Space, and the Freedom of Movement, edited by Nathalie Peutz and Nicholas De Genova, 262-294. Durham: Duke University Press. 